\title{
Phosphorus behaviour in a river during periods of drought and rain
}

\section{Charles Carneiro}

Higher Institute of Administration and Economy of Mercosur (ISAE), Curitiba, Brazil; Sanepar, Curitiba, Brazil (corresponding author: charlesc@sanepar.com.br) (Orcid:0000-0002-4593-9105)

\author{
Maurício B. Scheer \\ Sanepar, Curitiba, Brazil \\ Gustavo R. C. Possetti \\ Higher Institute of Administration and Economy of Mercosur (ISAE), \\ Curitiba, Brazil; Sanepar, Curitiba, Brazil
}

The behaviour of phosphorus forms and loads under conditions of drought and rainfall and based on real measurements was studied in the Timbú River Basin, an important water source in the metropolitan region of Curitiba, Paraná State, Brazil. Quantitative and qualitative chronosequential analyses were performed in different points of the river during a period of drought and every 5-10 min before, during and after rainfall in the basin. The main results showed that the phosphorus load at the river mouth during drought periods was $2.8 \mathrm{~kg} / \mathrm{d}$, five times lower than the normal flow of $8.8 \mathrm{~kg} / \mathrm{d}$. At its peak during medium rainfall, the load reached $175.3 \mathrm{~kg} / \mathrm{d}$, highlighting the significant influence of diffuse loads in the catchment area. The parameters total phosphorus and reactive phosphorus differed based on river compartments and land uses, mainly urban, agricultural and preserved areas. Therefore, basin action plans must consider varying weather conditions, including both drought and rainy periods, and implement long-term monitoring programmes.

\section{Introduction}

The region of Curitiba, Brazil, has very low water availability $\left(550 \mathrm{~m}^{3} /\right.$ year per inhabitant), with the only available sources coming from nearby river springs, thus requiring the need for water reservoirs. Water availability is one of the most crucial factors in the development of the region. However, this concern has been disregarded and population growth has accelerated environmental degradation.

The integrated water supply system of Curitiba provides $9495 \mathrm{l} / \mathrm{s}$ of treated water to about three million inhabitants (Sanepar, 2013). The Iraí and Iguaçu systems, which make up approximately $62 \%$ of this water supply, feed three of the four reservoirs operating in the region: Piraquara I, Piraquara II and Iraí (Sanepar, 2013). Lake Iraí is the largest and the most fragile, particularly in relation to eutrophication risk. The Timbú River Basin is one of the main tributaries of Lake Iraí, which contributes c. $93 \%$ of the phosphorus (P) pollution to the reservoir (Bollmann et al., 2005). Consequently, frequent macrophyte and cyanobacteria blooms have been observed in the ecosystem.

The importance of dissolved and particulate loads carried to waterbodies has been widely recognised for both natural and anthropogenic sources of pollution (Behrendt and Bachor, 1998; Danelon et al., 1991; Jambers et al., 1999; Kruawal et al., 2005; Rietzler et al., 2001). However, although non-point source pollution generally makes up the main fraction of the total phosphorus (TP) load, not only is this source of pollution difficult to measure and locate, but it is often underestimated or disregarded. The principal path of transport for non-point sources is rainfall due to the solubilisation and movement of nutrients to watercourses. Point loads, on the other hand, are mainly the result of urban occupation and the consequent irregular waste water connections or release of untreated sewage in areas where there is no sewage system (Bollmann et al., 2005).

As rainwater promotes the drag of particulate and dissolved materials, the evaluation of diffuse nutrient inputs must consider weather conditions and in particular the quantity and intensity of rainfall before, during and after events. Rainfall intensity, along with the chemical and physical properties of soil (texture, structure, moisture, cation-exchange capacity) and soil coverage, determines the magnitude and strength of the surface particle drag forces (Erpul et al., 2003; Sharpley and Halvorson, 1994; Sharpley et al., 1981). Thus, knowing about phosphorus inputs into the river and how it works, taking into consideration flows and weather circumstances, is quite important for basin and reservoir management.

The purpose of this study was to evaluate the behaviours of different forms of phosphorus concentrations and loads in waterbodies under varying weather conditions, mainly drought and rain events. To achieve this, water quality and flow at various points throughout the Timbú River Basin were assessed. Special attention was given to the relationship between concentration and flow, resulting in the TP load into the reservoir.

\section{Materials and methods}

Study area

The Timbú River Basin is a small basin $\left(26 \mathrm{~km}^{2}\right)$ located in the metropolitan region of Curitiba, Paraná State, southern Brazil $\left(49^{\circ} 35^{\prime}\right.$ west and $25^{\circ} 46^{\prime}$ south; see Figure 1).

The geological source material comes from Tertiary and Quaternary Periods. The predominant geological formation in the 


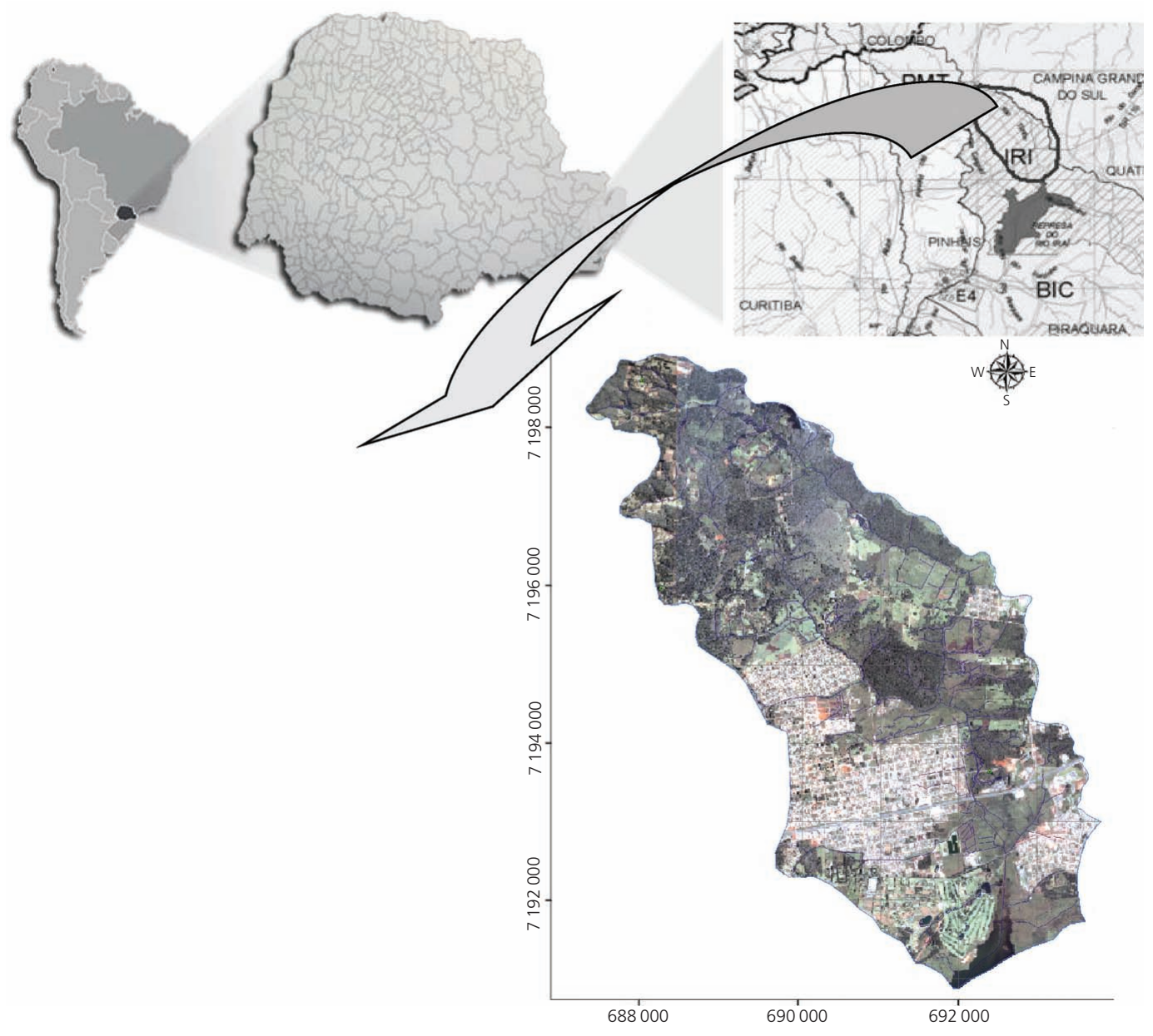

Figure 1. Location of the Timbú River Basin, Metropolitan Region of Curitiba, southern Brazil

area is the Guabirotuba Formation (Bigarella and Salamuni, 1962), which forms part of the sedimentary basin of Curitiba and contains montmorillonite and arkose with carbonate interlayers (Becker, 1982; Bigarella and Salamuni, 1962). These sedimentary units are deposited in erosive discordance on the basement rock layer (Salamuni et al., 1999). The weathering of substrate has resulted in a kaolinite aluminium silicate group, as well as iron oxides, hydroxides and oxyhydroxides. Clay fractions, in particular kaolinite and smectite, are prevalent, and oxyhydroxides, such as gibbsite and haematite, have also been identified (Fortin et al., 1989).

The elevation varies from 895 to $990 \mathrm{~m}$ above sea level (asl), creating $95 \mathrm{~m}$ of total vertical distance between the farthest spring and the river mouth. The region includes a range of landscapes and land reliefs, from flat to strongly undulating terrain (see Figures 2(a) and 2(b)).

The main land uses are $(a)$ natural and planted forests, $(b)$ fields and agriculture and $(c)$ urban areas (Figure 2(c)). There are several small farms in the area surrounding both streams. While mining and poultry farming no longer occur in the basin, temporary crops and vegetables are often planted on the left side of the catchment area, which demand large amounts of phosphate $\left(\mathrm{PO}_{4}{ }^{3-}\right)$ fertilisers (in particular corn and grass crops). The right side of the catchment is relatively well preserved. Exotic Pinus sp. plantations and bare soil areas are not extensive. Urban areas, concentrated in the lower third on the right side of the basin, are significant and promote greater amounts of run-off due to soil sealing (Figure 2).

According to Lima (2005), the Timbú River Basin has ten different soil types, taking into account the fourth hierarchic level (Embrapa, 1999), which can be found in isolation or associated with others typologies. The main soil type is clay-rich, composed of aluminium humic cambisol (inceptisol) and dystrophic humic cambisol (inceptisol) (Table 1), and occupies 35\% of the total area (Figure 2).

The Timbú River is composed of two main unnamed streams, which run across two-thirds of the basin, resulting in an average flow across the mouth of the Timbú River of $c .0 \cdot 430 \mathrm{~m}^{3} / \mathrm{s}$ (SGP, 2000). 
Journal of Environmental Engineering and Science

Volume 13 Issue JS4
Phosphorus behaviour in a river during

periods of drought and rain

Carneiro, Scheer and Possetti

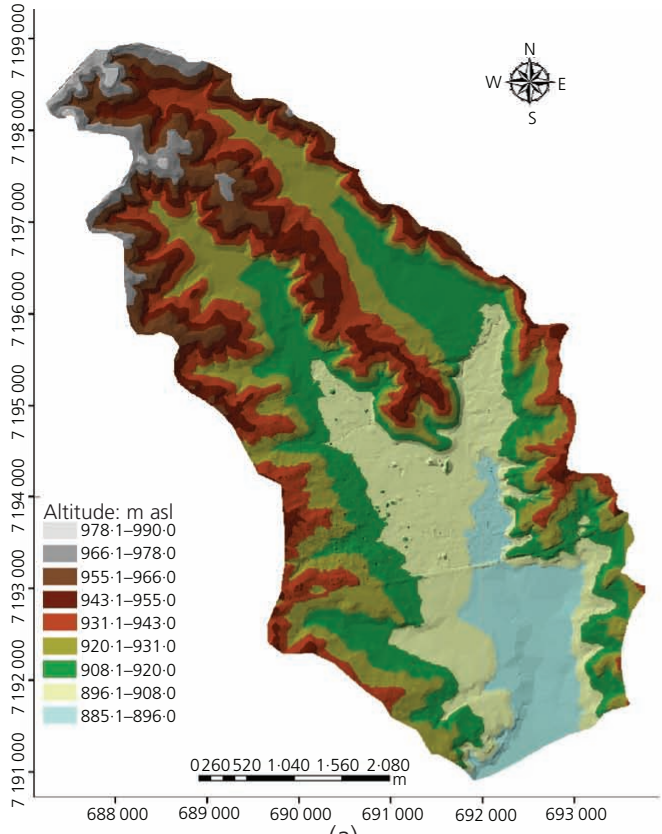

(a)

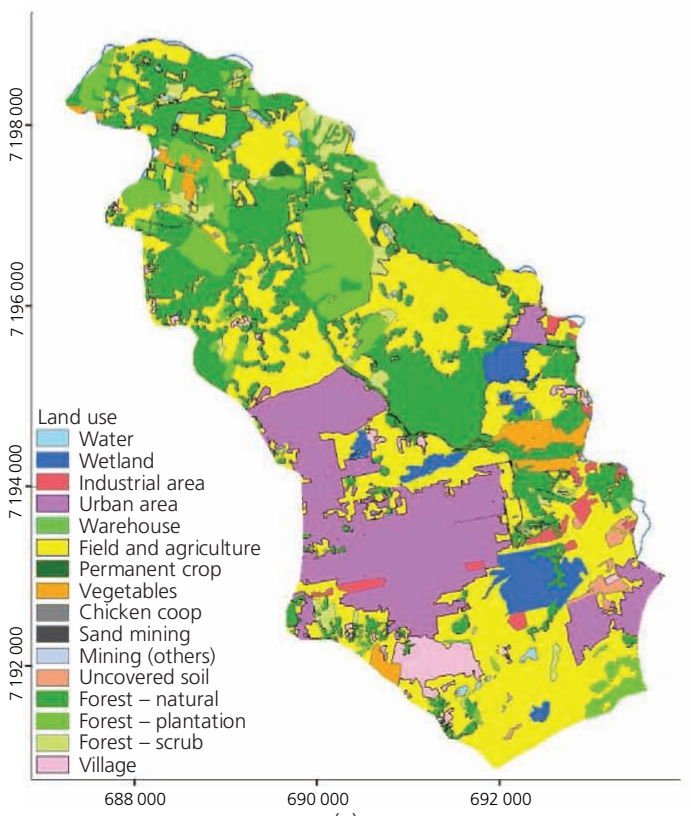

(c)

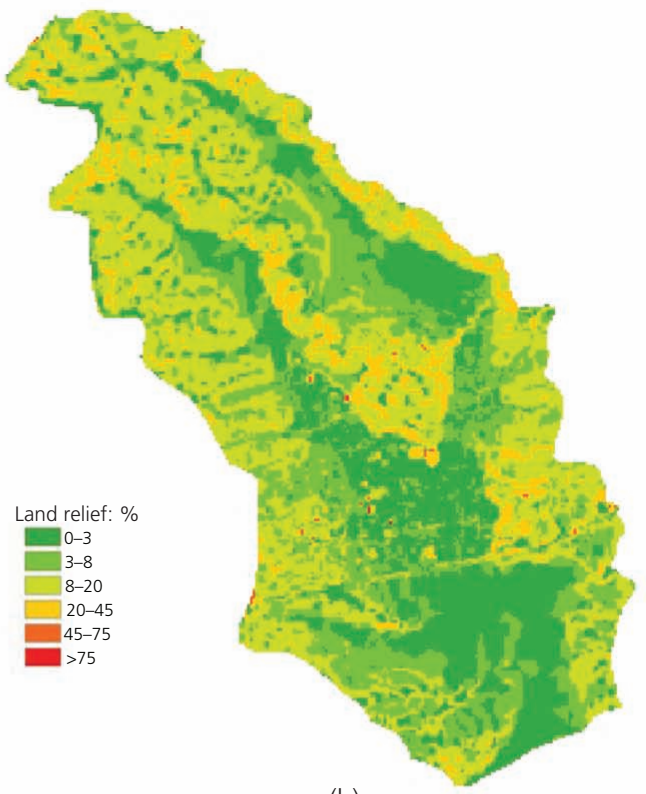

(b)

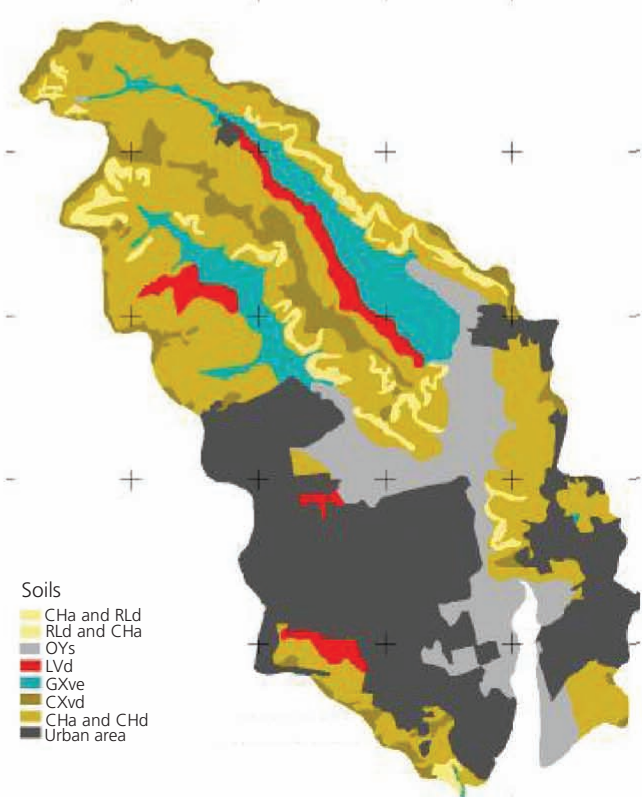

(d)

Figure 2. (a) Altitude, (b) terrain, (c) land use and (d) soils of the Timbú River Basin, southern Brazil

\section{Experimental and statistical procedures}

The evaluation of phosphorus behaviour in the Timbú River was carried out during three distinct situations throughout 2006: (a) period of drought, (b) light rain (drizzle $-4.9 \mathrm{~mm}$ ) and (c) medium rain $(16.8 \mathrm{~mm})$. The sampling sites were defined based on land use, drainage, elevation and how well the site represents upstream land use (see Figure 3). The phosphate series analysed were TP, dissolved phosphorus $\left(\mathrm{P}_{\text {dissolved }}\right)$, reactive phosphorus $\left(\mathrm{P}_{\text {reactive }}\right)$ and dissolved reactive phosphorus ( $\left.\mathrm{P}_{\text {reactive dissolved }}\right)$ (essentially orthophosphate).
- Situation 1: $12 \mathrm{~d}$ without rain events before sampling. The river was partitioned into 34 sampling points (Figure 3). All samples were obtained in $1 \mathrm{~d}$.

- Situations 2 and 3: light rain (drizzle) of low intensity $(4.9 \mathrm{~mm})$ and rain of medium intensity $(16.8 \mathrm{~mm})$. For both situations, chronosequential water samples were taken simultaneously at four different points (Figure 3), as follows

(i) 27BU (before urbanisation): area with good agricultural management practices, forest relatively well preserved, 
Table 1. Main features related to phosphorus behaviour in the Timbú River Basin, southern Brazil

\begin{tabular}{|c|c|}
\hline Item & Information \\
\hline \multicolumn{2}{|l|}{ Morphometric } \\
\hline Total area basin: $\mathrm{km}^{2}$ & 26 \\
\hline $\begin{array}{l}\text { Greatest length - } \\
\text { waterway: km }\end{array}$ & $10 \cdot 6$ \\
\hline Mouth width: m & $5 \cdot 85$ \\
\hline Altitude: $m$ asl & $885-990$ \\
\hline Land relief & Flat to undulating \\
\hline \multicolumn{2}{|l|}{ Hydrological } \\
\hline Number of main streams & 2 \\
\hline Mean depth: m & $0 \cdot 35$ \\
\hline Mean flow: $\mathrm{m}^{3} / \mathrm{s}$ & 0.43 \\
\hline Mean velocity: $\mathrm{m} / \mathrm{s}$ & $0 \cdot 22$ \\
\hline \multicolumn{2}{|l|}{ Weather $^{a}$} \\
\hline Köppen climate zone & Humid temperate \\
\hline Annual mean temperature: ${ }^{\circ}{ }^{\circ} \mathrm{C}$ & 17 \\
\hline $\begin{array}{l}\text { Mean minimum temperature - } \\
\text { coldest months: }{ }^{\circ}{ }^{\circ} \mathrm{C}\end{array}$ & $8-10$ \\
\hline $\begin{array}{l}\text { Mean maximum temperature - } \\
\text { hottest months: }{ }^{\circ}{ }^{\circ} \mathrm{C}\end{array}$ & $23-27$ \\
\hline $\begin{array}{l}\text { Last } 20 \text { years' annual average } \\
\text { precipitation: } \mathrm{mm}\end{array}$ & 1800 \\
\hline $\begin{array}{l}\text { Annual average } \\
\text { precipitation: }^{\text {a }} \mathrm{mm}\end{array}$ & 1602 \\
\hline $\begin{array}{l}\text { Mean rainiest month - } \\
\text { January: }{ }^{a} \mathrm{~mm}\end{array}$ & 174 \\
\hline $\begin{array}{l}\text { Mean driest month - } \\
\text { April: }{ }^{\mathrm{a}} \mathrm{mm}\end{array}$ & 55 \\
\hline $\begin{array}{l}\text { Mean highest intensity rain - } \\
\text { March: }{ }^{a} \mathrm{~mm} / \mathrm{h}\end{array}$ & $2 \cdot 15$ \\
\hline \multicolumn{2}{|l|}{ Lithopedological } \\
\hline Soil: \% & Ten types (main inceptisol - 35) \\
\hline Geology & $\begin{array}{c}\text { Mudstone, arkoses and alluvial } \\
\text { deposits }\end{array}$ \\
\hline Urban areas: \% & $30 \cdot 7$ \\
\hline \multicolumn{2}{|l|}{ Vegetation } \\
\hline Forest: main composition & $\begin{array}{l}\text { Myrtaceae and Fabaceae } \\
\text { (montane - mixed rainforest) }\end{array}$ \\
\hline Riparian forest: \% & 39 \\
\hline Missing or damaged forest: \% & 61 \\
\hline
\end{tabular}

non-intense land use; located between right stream sources and the beginning of urban area

(ii) 80AU (after urbanisation): area with intense urban land use; located between point BU and the beginning of river mouth (MR)

(iii) 12IA (intensive agriculture): area with extensive agricultural use with poor management practices; located between left stream sources and the beginning of point $\mathrm{MR}$

(iv) 52MR (river mouth): area that receives all loads from the basin; located between points AU and IA and represents a reservoir/river intersection zone.
The chronosequential sampling under low-intensity rainfall $(4.9 \mathrm{~mm})$ resulted in seven samples at point $27 \mathrm{BU}$ over $82 \mathrm{~min}$ and four samples at points 80AU, 12IA and 52MR, over 136, 143 and $156 \mathrm{~min}$, respectively.

Under medium-intensity rainfall $(16.8 \mathrm{~mm}), 11$ samples were taken for each of the four points as follows: the first ten samples were taken before, during and after rainfall over a period of $90 \mathrm{~min}$ at 27BU, $121 \mathrm{~min}$ at $80 \mathrm{AU}$ and 12IA and $107 \mathrm{~min}$ at MR. The 11th sample was taken $14 \mathrm{~h}$ after the tenth sample to determine if water quality returned to pre-rain conditions.

The flow rates were measured concomitantly with sample taking. Because of different morphometric characteristics at each point, different methods were used to determine the flow, as follows: 27BU - California method, case of horizontal ducts; 80AU and 12IA - hydrometric reel; 52MR - estimated by Manning's equation, uniform and constant flow.

Scatter plots were used to demonstrate the behaviour of the parameters, and Pearson's correlation coefficient $(r)$ was used to detect the relationships between phosphorus forms and flows.

\section{Results and discussion}

Reportedly, weather phenomena are more intense over the past decades, particularly due to climate changes. Rainfall and drought events have behaved differently and are more severe than they have been historically (Unesco, 2015, 2016). A recent study by Ayanlade et al. (2018) has shown a very high spatial variability between stations, temporal variability, and, in consequence, there are several anomalies in rainfall in recent years. Thus, understanding the behaviour of the river basin plays a vital role in managing and protecting the ecosystem.

As expected, there were relevant differences among all three scenarios analysed. Under the drought condition a phosphorus concentration effect was observed, whereas during rainfall the effects of both the phosporus concentration and the behaviour of the river basin were observed.

Response managers should follow the monitoring of these different conditions. Water quality monitoring programmes and databases play a crucial function in defining activities across the basin, principally in anticipating potential problems.

\section{Drought period}

As expected, water flows in the basin and their loads were markedly lower than normal during periods of drought. In this situation, artificially released effluents become determinants in water quality patterns and are also easier to detect. This corroborates with the statement that base flow concentrations (or at non-high-flow events) are most ecologically relevant to analysing flowing waters (Stamm et al., 2014). High TP concentrations were found at sampling points with low flow levels, most of which occur in tributary channels, such as 26 


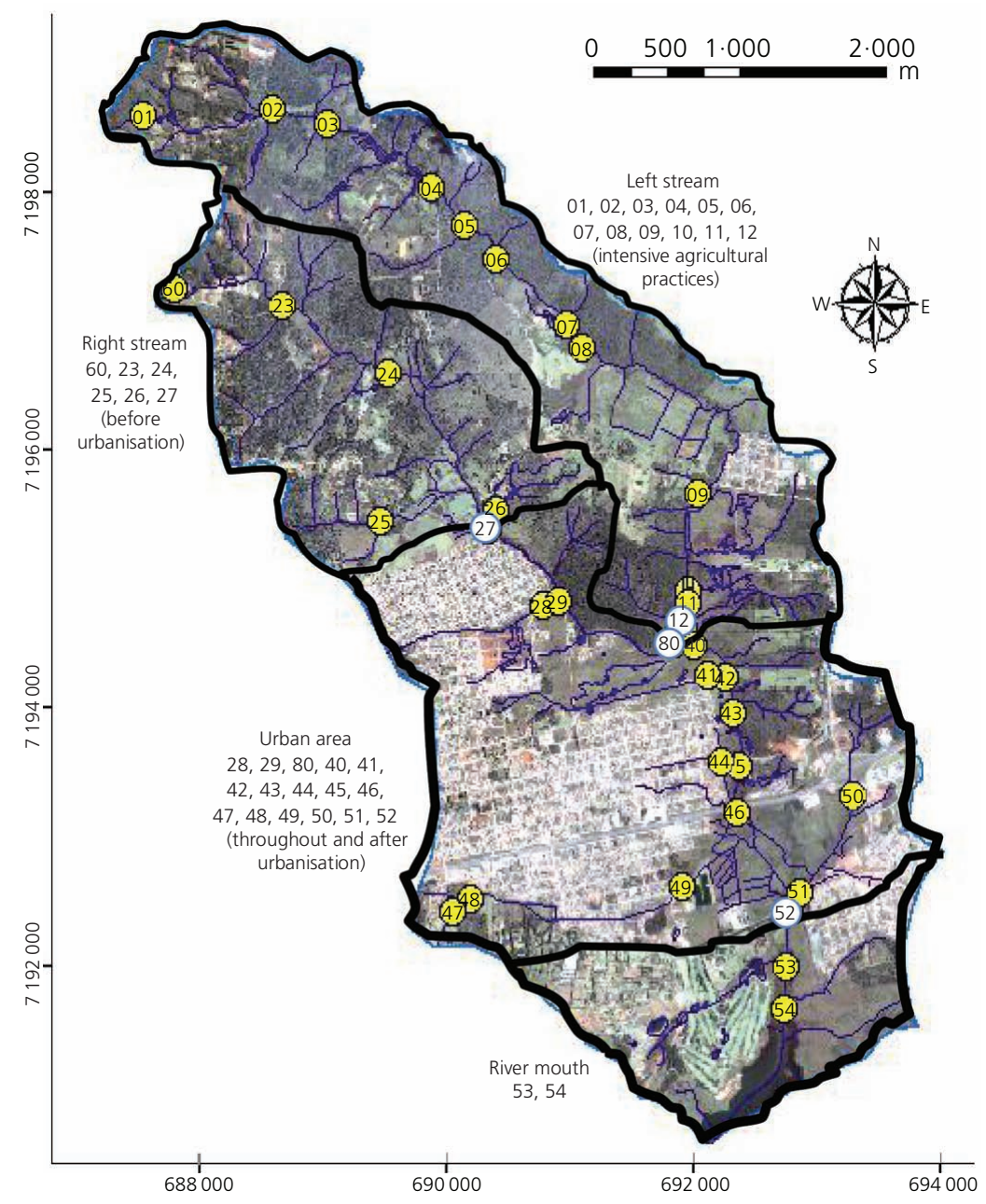

Figure 3. Sampling stations: drought period (yellow) and rainy period (white) in the Timbú River Basin, southern Brazil

(BU, although it has a village upstream) and 28, 47, 49, 50 and 51 (all AU) (Figure 4). Among low-flow sampling points, only 25 (BU) and 48 (AU) had a low TP content. High TP concentrations are expected from waterways with reduced flow in urban areas.

A considerable number of these points also had high

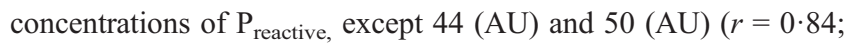
$p \leq 0 \cdot 05$; for $\left.\mathrm{TP} \times \mathrm{P}_{\text {reactive }}\right)$. The correlation coefficients between flow and TP concentration $(r=0 \cdot 14 ; p \leq 0.05)$ and flow and $\mathrm{P}_{\text {reactive }}(r=-0.24 ; p \leq 0.05)$ indicate that the highest concentrations are not directly correlated with greater flow. Point 12IA, further downstream on the left tributary, had a TP concentration $(50 \mu \mathrm{g} / \mathrm{l})$ significantly lower than that of point 29 (AU), located downstream on the main axis of the right tributary $(1160 \mu \mathrm{g} / \mathrm{l})$, which is affected by the first large urban area (pollution from the Eugênia Maria housing estate). Before this housing complex, a considerably lower TP concentration $(30 \mu \mathrm{g} / \mathrm{l})$ was observed. The first point after confluence (40AU) presented $380 \mu \mathrm{g}$ TP/l. Thus, the $1 \mathrm{~km}$ distance between points 29 (AU) and
40 (AU) reduced TP concentrations due to TP dilution and purification processes probably resulting from greater flow and the presence of iron (III) $\left(\mathrm{Fe}^{3+}\right)$ and aluminium $\left(\mathrm{Al}^{3+}\right)$ oxyhydroxides and/or biological utilisation (Stamm et al., 2014).

All sampled points after confluence maintained high TP values, even with increased flow, which suggests that the increased flow cannot dilute or sink the loads coming into the river. The Paulista housing estate (points 41-49) contributes significant loads to the river mouth point (52MR) despite its high level of sanitation of greater than $80 \%$ (Sanepar, unpublished data). Small amounts of untreated sewage can lead to considerable phosphorus loads as a result of their high phosphorus concentrations.

\section{Light rain (drizzle $-4.9 \mathrm{~mm}$ )}

In the second stage of this study, light-rain conditions were evaluated: $4.9 \mathrm{~mm}$ at point $27 \mathrm{BU}, 1 \mathrm{~mm}$ at points $12 \mathrm{IA}$ and $80 \mathrm{AU}$ and $0 \mathrm{~mm}$ at the river mouth region 52MR. This event did not produce significant changes to water flow throughout the period of rain (about $73 \mathrm{~min}$ ) (Figure 5). 


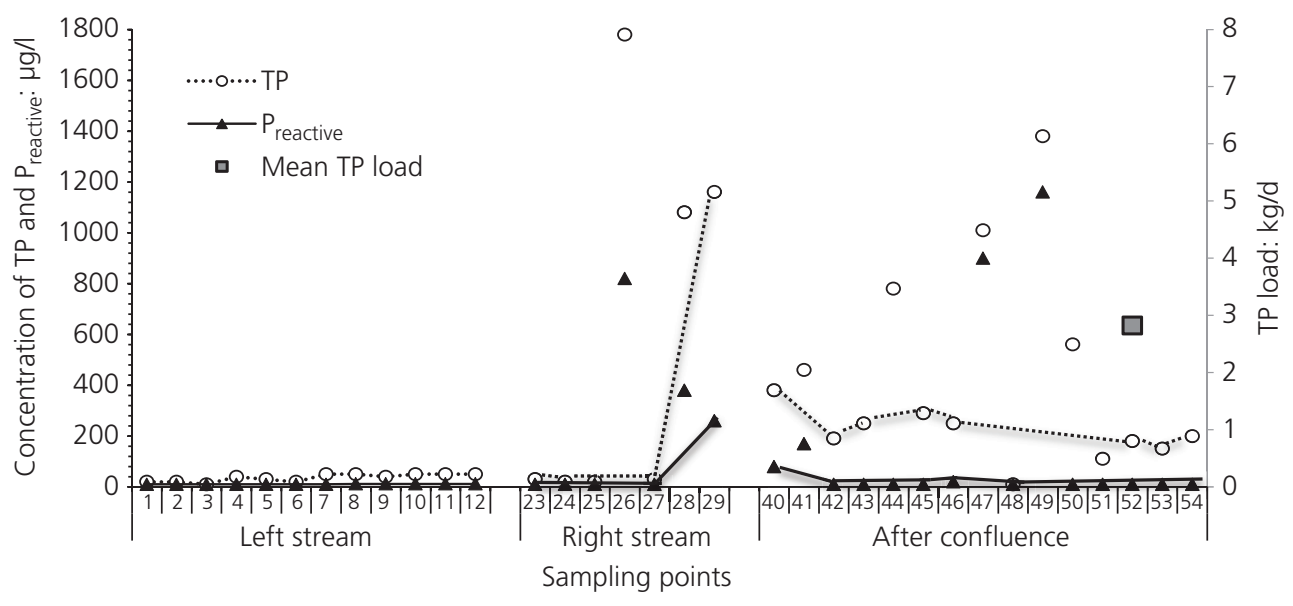

Figure 4. TP and $\mathrm{P}_{\text {reactive }}$ concentration in Timbú River Basin during the drought period. Note: connected points belong to the main stream waterway

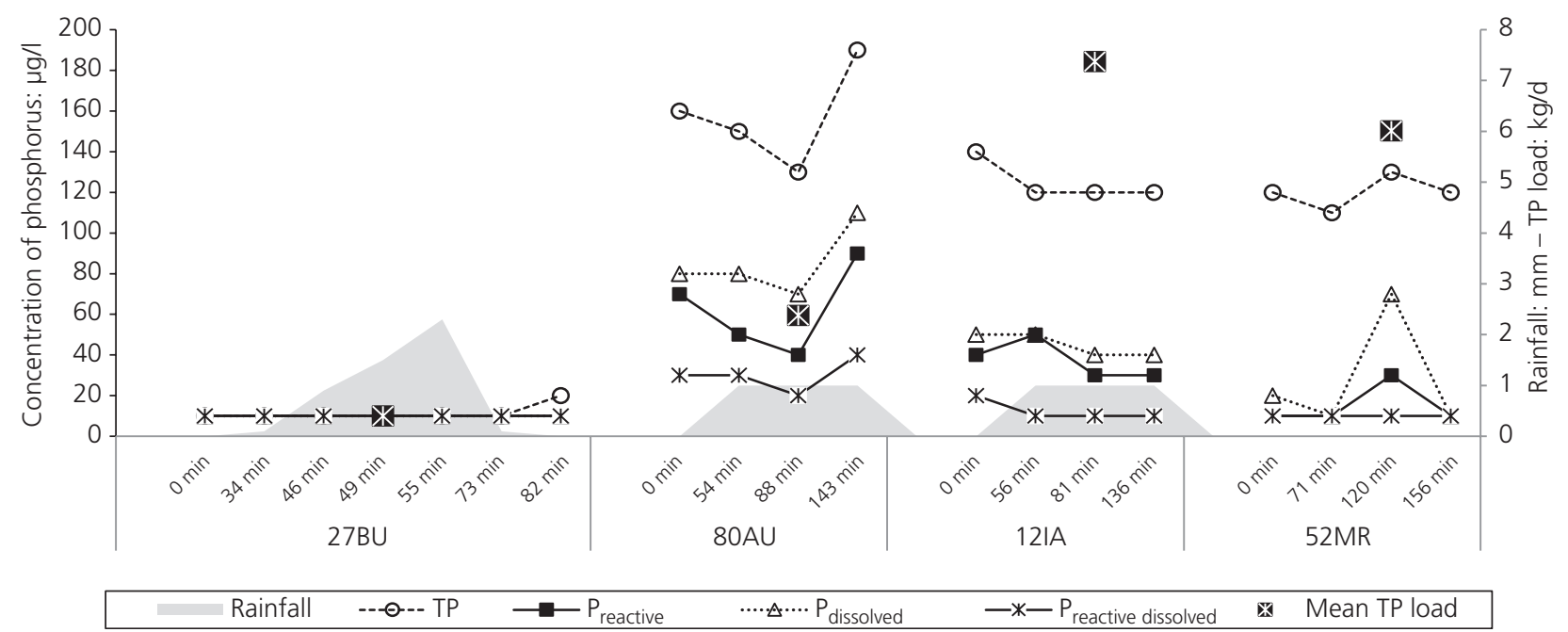

Figure 5. TP, $P_{\text {reactive, }} P_{\text {dissolved }}$ and $P_{\text {reactive dissolved }}$ concentrations, mean TP loads and rainfall for four sampling stations in the Timbú River Basin during light-rain conditions $(4.9 \mathrm{~mm})$

The behaviour of the phosphorus forms was relatively homogeneous. However, all phosphorus forms observed at $80 \mathrm{AU}$ (anthropogenic influence) had higher values at $143 \mathrm{~min}(0 \cdot 190 \mathrm{mg} / \mathrm{l})$ than the previous sample times. This increase can be related to rain in the basin and to the movement of the water flow upstream (from point 27BU), causing the transport of suspended particulates and sediment (Figure 5). Before the observed rain effects at points $80 \mathrm{AU}$ and $52 \mathrm{MR}$, the influence of land use was clear in all measured phosphorus forms, with the highest ' 0 min' value found after urbanisation 80AU (Figure 5). The $4.9 \mathrm{~mm}$ precipitation that occurred in the region of point 27BU did not influence phosphorus concentrations, which is likely the result of a lack of precipitation upstream. The phosphorus contributions are therefore essentially diffuse. Similarly, the $1 \mathrm{~mm}$ rain did not result in considerable changes in phosphorus concentrations at 12IA, which, like 27BU, receives loads primarily in diffuse form (see Figure 5).
The reactive orthophosphate values (between $0 \cdot 01$ and $0.90 \mathrm{mg}$ phosphorus/1; Figure 5) are in the same range as those found by Ramanathan et al. (1999) of 0.016-0.767 mg phosphate/l $(\chi=$ $0.280 \mathrm{mg}$ phosphate/l). The authors associated their observed values to the anthropogenic and agricultural influences in the basin, in particular the use of the diammonium phosphate fertiliser, among other contributions. Sharpley and Halvorson (1994) found run-off values around $0.009 \mathrm{mg}$ phosphorus/1 in forests and $0.071 \mathrm{mg}$ phosphorus/1 in agricultural areas. A similar average $(0.056 \mathrm{mg}$ phosphorus $/$; from 0.032 to $0.375 \mathrm{mg}$ phosphorus/l) was reported by Defew et al. (2013) in a stream of an intensively farmed catchment.

The highest TP loads were observed at points 12IA and 52MR, in contrast to expectations that point $80 \mathrm{AU}$ would be higher. The results showed that under drought periods, flow has a greater influence on 
loads than concentrations. The drag of phosphorus depends on rain events; therefore, the decreased TP load at the river mouth (point $52 \mathrm{MR}$ ) is due to an absence of rain in this zone (Figure 5).

\section{Medium rain ( $16.8 \mathrm{~mm}$ )}

For this condition, the amount of rain varied according to sample points, as follows: $27 \mathrm{BU}=16.8 \mathrm{~mm} ; 12 \mathrm{IA}=15 \mathrm{~mm} ; 80 \mathrm{AU}=$ $15 \mathrm{~mm}$; and $52 \mathrm{MR}=15 \cdot 7 \mathrm{~mm}$ (Figure 6).

The flow at point $80 \mathrm{AU}$ had a much greater increase than at point 12IA. Despite similar initial flows, the differences between the observed peaks at the points after urbanisation and after intensive agriculture $\left(0.575\right.$ and $\left.0.283 \mathrm{~m}^{3} / \mathrm{s}\right)$ suggest that the impermeability in the $80 \mathrm{AU}$ subbasin is very high, leading to pronounced run-off. The river mouth point $(52 \mathrm{MR})$ reached $2 \cdot 229 \mathrm{~m}^{3} / \mathrm{s}$, which is ten times greater than the initial flow (Figure 6).

Unlike the observed drought or the light-rain conditions, the period of medium rainfall not only showed greater run-off from urban areas but also showed increased TP concentrations and consequently loads (Figure 7). This increase is likely due to problems in municipal sanitation, because of either a lack of an appropriate sewer system or pipe structural problems, thus further deteriorating the quality of the waterbody.

The behaviour of phosphorus concentration was different among the sample points. At point $80 \mathrm{AU}$, a greater influence of run-off was observed than at the other points. Clearly, at this point, the TP load peak (Figure 6), as well as TP concentration peak (Figure 7), is related to the hydric increment at $47 \mathrm{~min}$. TP concentration increased again at $95 \mathrm{~min}$, even after the rain in the basin ended. Considering that both load and flow decreased, this late increase is likely related to the drag of some rich source of this element.

The differences in TP concentration peaks (as well as TP loads) between neighbouring points 80AU and 12IA, which have similar drainage areas, confirm the influence of different land uses. Point 80AU apparently indicates a high level of soil sealing, while 12IA likely shows greater field roughness and consequently higher levels of infiltration (Figures 6 and 7). While TP concentrations observed at $80 \mathrm{AU}$ and 52MR were high before the rainfall, during the event, the values increased considerably, particularly in the region downstream of urbanisation. As such, these values depend largely on land management. In a similar study, $31 \%$ of the TP loads were attributed to eroded material from crops, $30 \%$ from domestic sewage, $12 \%$ from inappropriate agricultural use, $10 \%$ treated rainwater, $10 \%$ industrial effluents and 7\% other sources, such as urban drainage, groundwater and rainfall (Umweltbundesamt, 1997: pp. 234-236).

The agricultural regions (27BU and 12IA) showed $\mathrm{P}_{\text {reactive }}$ concentrations higher than $\mathrm{P}_{\text {dissolved, even during rainfall. The }}$ urbanised subbasins (80AU and 52MR) presented the opposite; dissolved phosphorus forms were observed at the beginning and during rainfall and were exceeded only by reactive forms after the rain had influenced the flow. Low-molecular-weight organic compounds containing phosphorus, such as amino acids and other substances from urban sources, can promote an increase in $\mathrm{P}_{\text {dissolved }}$ concentrations before rain. Under light-rain conditions $(4.9 \mathrm{~mm})$, when the effects of run-off were not pronounced, higher concentrations of the dissolved forms were also found instead of
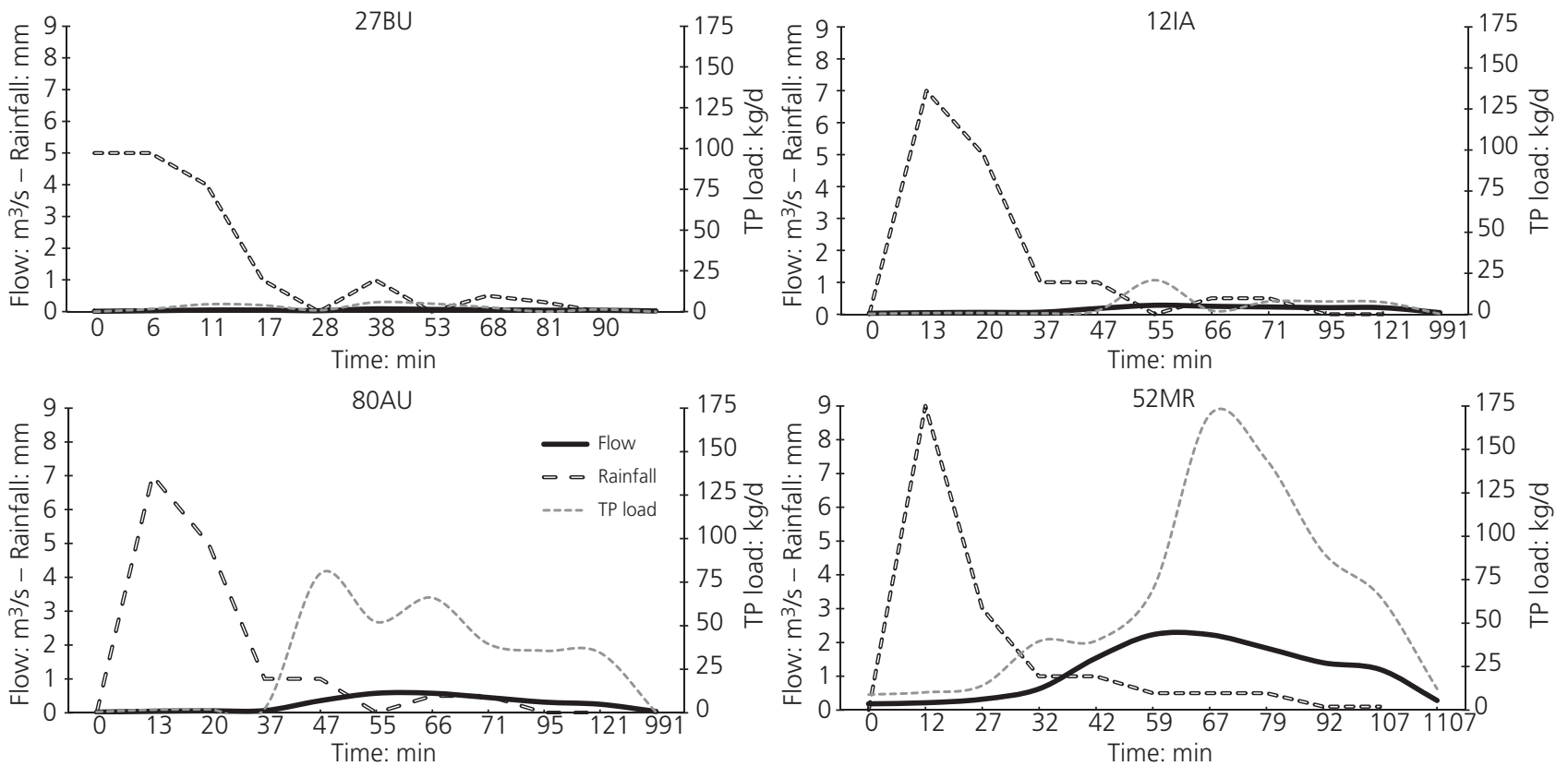

Figure 6. Rainfall, flow and TP load at four sampling stations in the Timbú River Basin during medium-rain conditions (15-16.8 mm) 

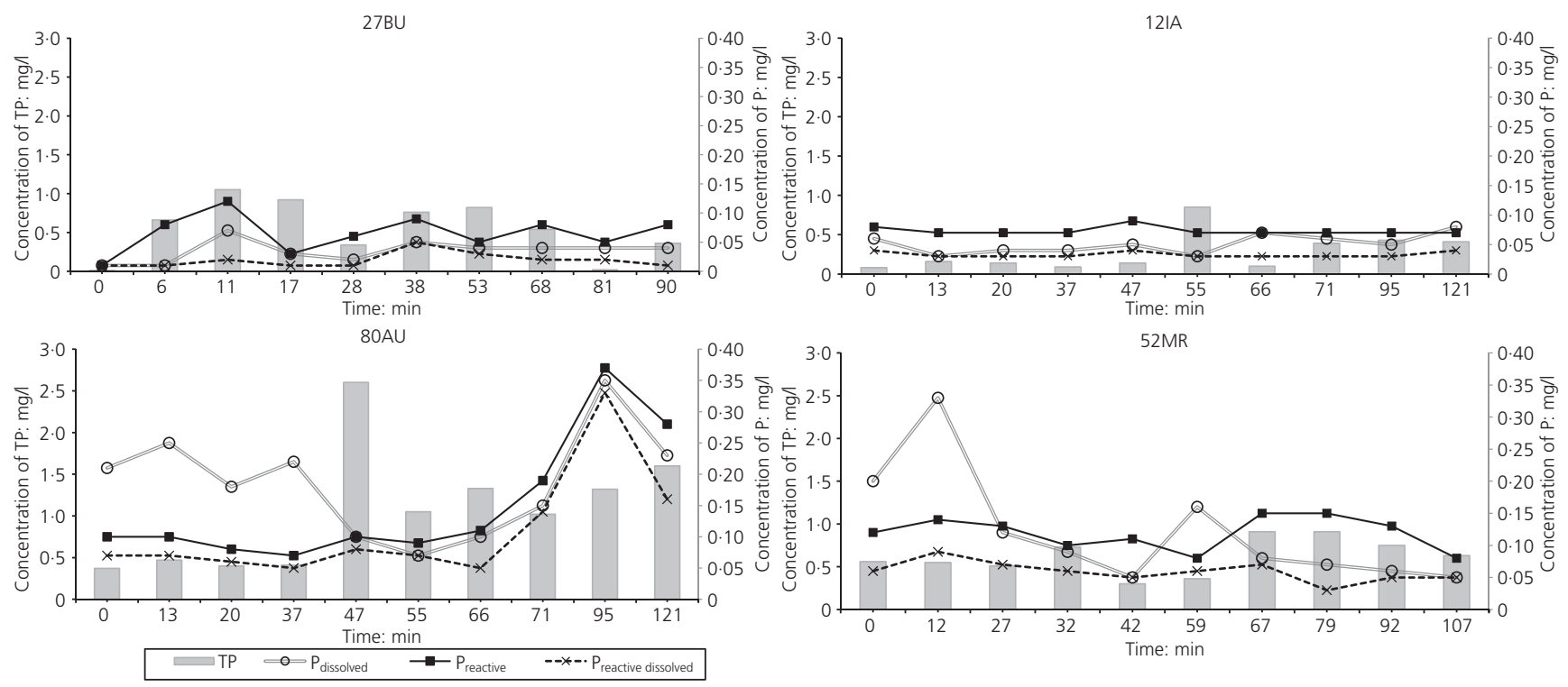

$52 \mathrm{MR}$

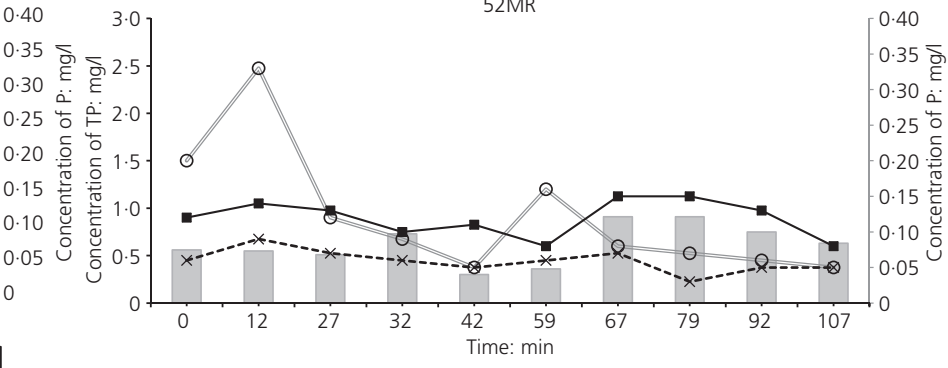

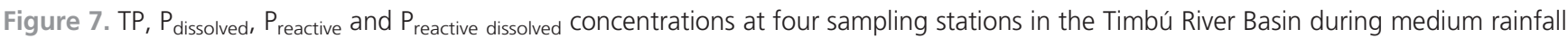
$(16.8 \mathrm{~mm})$. Flow is shown in Figure 6

reactive phosphorus forms. An increase in $\mathrm{P}_{\text {reactive }}$ was detected only with an increase in flow at $47 \mathrm{~min}$ (peak at $95 \mathrm{~min} ; 0.37 \mathrm{mg} / \mathrm{l}$ ). Therefore, the run-off was responsible for the reactive forms, which were negligible in the absence of diffuse pollution. The $\mathrm{P}_{\text {reactive }}$ concentration at $80 \mathrm{AU}$ after $14 \mathrm{~h}$ decreased to $0.08 \mathrm{mg} / \mathrm{l}$ and $\mathrm{P}_{\text {dissolved }}$ to $0.04 \mathrm{mg} / 1$, supporting the aforementioned statement. The reactive phosphorus forms are immediately available for phytoplankton and aquatic macrophyte uptake. $\mathrm{P}_{\text {reactive }}$ and $\mathrm{P}_{\text {dissolved }}$ present similar behaviours in all regions, suggesting a relative equilibrium between phosphorus from particulate and solubilised materials.

At points 27BU and 12IA, TP concentrations were considerably higher than dissolved and reactive forms (Figure 7). This suggests that a large proportion of TP found was in organic form, with predominantly non-soluble molecules, or as attached to clay materials. Higher increments observed for phosphorus in water can be attributed to its significant fixation with aluminosilicates (Mackenthun et al., 1964). From this, phosphorus could come from the dragging of organic particulates, litter, agricultural crop residue or organic waste from farm activities such as fishing, while the source of mineral inputs can be fertilisers and aluminosilicates.

At point 52MR, rainfall had little influence on the observed phosphorus forms, confirming that with greater river flow, a greater amount of rainfall is required to bring about significant changes to normal phosphorus levels (Figure 7).

\section{TP load behaviour}

Generally, increases in flow result in increases in TP loads. In addition, when a particular segment of the river is measured during a rainfall event, the dragging potential of particulate materials by run-off and the solubilisation potential of chemical elements are the determining factors in higher or lower loads. Obviously, both transport and solubilisation processes depend on morphological, physical, chemical and biological features.

During the observed drought condition, TP load at 52MR was $2 \cdot 8 \mathrm{~kg} / \mathrm{d}$, for an estimated flow of $0 \cdot 185 \mathrm{~m}^{3} / \mathrm{s}$ (Figure 4). This load can be considered low, as was the water flow, which was four times lower than the average flow reported in the publication by the State Government of Parana (SGP, 2000) of $0.430 \mathrm{~m}^{3} / \mathrm{s}$. The maximum TP load for the maintenance of a mesotrophic state in the Iraí Lake is limited to $18.7 \mathrm{~kg} / \mathrm{d}$ (Franz et al., 2007). However, the results of another study (Gobbi, personal communication) suggested that the TP load should be less than $2.3 \mathrm{~kg} / \mathrm{d}$ for the maintenance of a mesotrophic state.

Under conditions of low-level rainfall (drizzle of $4.9 \mathrm{~mm}$ ), the increased flow led to an increased TP, reaching $6.01 \mathrm{~kg} / \mathrm{d}, 214 \%$ higher than the drought load observed at point 52MR (Figure 5). During this event, the highest TP load $(7 \cdot 37 \mathrm{~kg} / \mathrm{d})$ was observed before the river mouth (point $80 \mathrm{AU}$ ). This is likely due to the location of the sampling point, which is downstream of pollution inputs from an urban area, where infiltration is reduced and runoff is increased, and downstream of point 27 (IA), where the highest amount of rainfall occurred.

During medium-rainfall conditions $(16 \cdot 8 \mathrm{~mm})$, significant variations in TP loads did not occur at points 27BU and 12IA (both influenced by agriculture and livestock) (Figure 6), except for a slight peak at $56 \mathrm{~min}$ at point 12IA. Therefore, agricultural land use with pastures and riparian forest delayed and retained possible TP loads. Additionally, the points within urbanised areas had flow and TP concentration peaks earlier and with greater intensities. 
At $47 \mathrm{~min}$, point $80 \mathrm{AU}$ showed an increase in TP concentration, which is likely related to the incoming of run-off causing a load peak. Later, even with increased flow $(55-66 \mathrm{~min})$, the load intensity decreased, suggesting that the wetting front was responsible for the greater phosphorus load.

Point 52MR is the last point in the Timbú River waterway and can be considered the most representative point for measuring total load inputs from the basin to the reservoir. The variation in flow caused by the medium rainfall $(16.8 \mathrm{~mm})$ was considerable. Before the rain, TP load was $8.8 \mathrm{~kg} / \mathrm{d}$, and during flow peak, it reached up to $175.3 \mathrm{~kg} / \mathrm{d}$; $14 \mathrm{~h}$ after rainfall, the load regressed to $12 \cdot 2 \mathrm{~kg} / \mathrm{d}$, slightly higher than pre-event levels. These values highlight the importance of rainfall events for phosphorus loads, even in drizzle conditions (low-intensity precipitation). Clearly, samples taken for monitoring water quality must consider pluviometric variables, since the rain events vary significantly and there are uncertainties associated with weather conditions. In these episodic events, phosphorus load metrics assume greater ecological relevance to help management of the downstream standing waters (Stamm et al., 2014). If regulatory authorities cannot increase sampling frequency due to financial or resource constraints, it is recommended to focus in high-flow events during their sampling programmes (Defew et al., 2013).

The estimated TP load from Timbú River throughout 2006 (10 $453 \mathrm{~kg}$; Figure 8) were similar to those estimated for the four main reservoir tributaries (including the Timbú River) from 2009 to 2012 as follows: $10425,10623,9098$ and $9387 \mathrm{~kg} \mathrm{TP} /$ year (Carneiro, unpublished data). This considerable contribution from a single tributary indicates that although improvements in the sanitation system have been undertaken, they are insufficient to solve the problem.

Although medium rain occurred only during $53 \mathrm{~d}$ of the year, this condition seems to contribute the largest TP loads throughout the year $(80.8 \%$ of inputs). The frequent drizzle conditions (222 d) represent $17 \%$ of loads, while drought $(90 \mathrm{~d})$ represents only $2 \cdot 2 \%$ of TP inputs (Figure 8 ).

It is important to highlight that the estimates of catchment discharge and nutrient loads are subject to aleatory and epistemic uncertainties (Hollaway et al., 2018). So, for a broad monitoring quality programme and calibration models, these aspects cannot be neglected.

\section{Conclusions}

From quantitative and qualitative chronosequential analysis at different points along the Timbú River - an important tributary of Iraí reservoir - the behaviour of phosphorus concentrations and loads was assessed, taking into account drought and rainfall conditions and based on real measurements.

The analysis of distinct phosphorus forms enabled to distinguish environments related to land use. The water-quality assessment considering different land uses showed that agriculture and urbanised areas provide greater phosphorus inputs compared to forest well-preserved areas. In river and streams with adjacent urbanised areas, considerably higher levels of TP and $\mathrm{P}_{\text {reactive }}$ were found, independently of rain or drought conditions.

The TP load peaks occurred after the increasing of flow over the points 12IA (intensive agriculture) and 52MR (river mouth), suggesting that the greatest loads came from upstream and, mainly, the preponderant weight of flow in the total load.

At the mouth of the river (52MR), a TP load of $2.8 \mathrm{~kg} / \mathrm{d}$ was observed in drought conditions. During periods of annual average flow, TP loads of $8.8 \mathrm{~kg} \mathrm{TP} / \mathrm{d}$ can be expected. During rainfall of $16.8 \mathrm{~mm}$, the load reached a maximum of $175 \cdot 3 \mathrm{~kg} \mathrm{TP} / \mathrm{d}(20$ times greater), underscoring the influence of diffuse pollution on

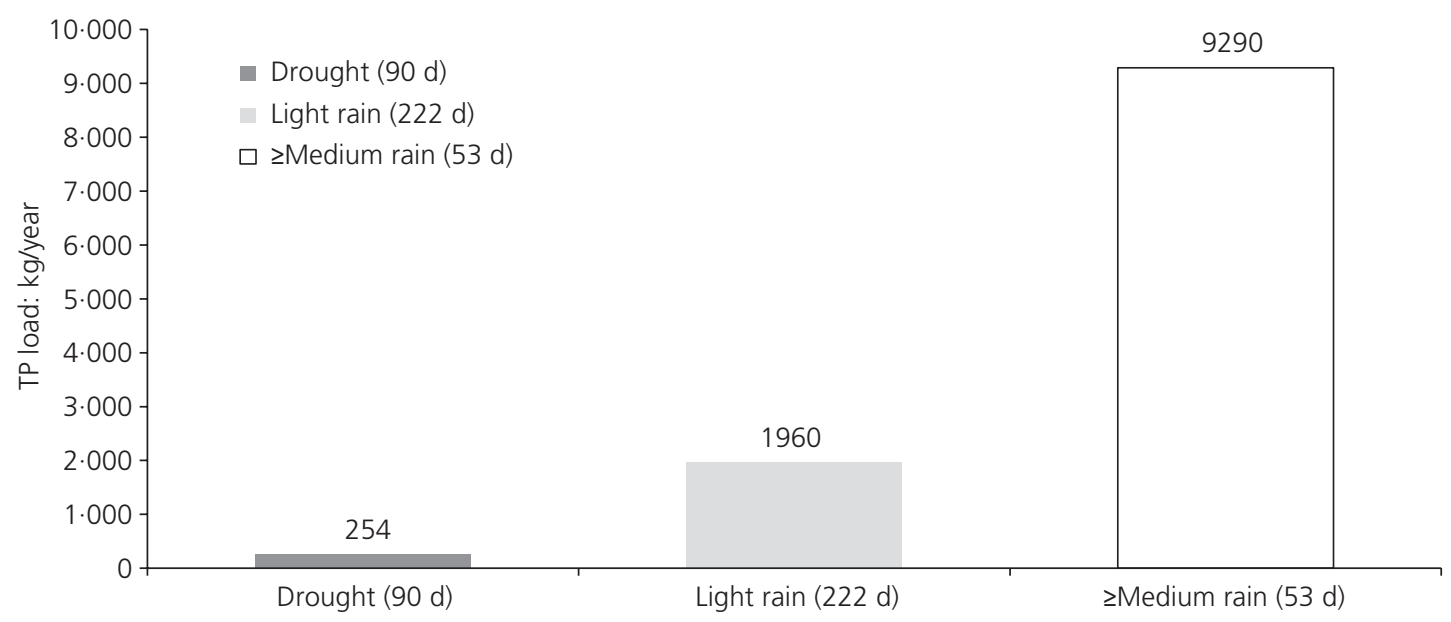

Figure 8. TP loads from the Timbú River to Iraí Reservoir in three different weather conditions during 2006: drought, light rain (drizzle $4.9 \mathrm{~mm}$ ) and medium rain $(16.8 \mathrm{~mm})$ 
river water quality. The total phosphorus load should be less than $2 \cdot 3 \mathrm{~kg} / \mathrm{d}$ to avoid eutrophication processes in the lake.

The variability in water quality during the presence or absence of rainfall in the basin indicates that management strategies must be based on monitoring programmes in order to account for such wide fluctuations. Furthermore, these programmes should take into account the uncertainties associated with rain events and observational data.

\section{Acknowledgements}

Sincere thanks are given to Dr André Bittencourt (Universidade Federal do Paraná (UFPR)) and the authors' colleagues Fábio Cunha, Paulo Neves, Josete F. de Sá, Rafael Cabral, Patrícia Lagos, Rafaela Mussi, Júlio Valaski, Gabriel Fares, Camila Scucato and Valérie Buffard (sampling team); Débora Kimura and Luciana Borges (GIS team); and Eve Nimmo (grammar team). The authors also thank the Sanepar and UFPR institutions for their support of this work.

\section{REFERENCES}

Ayanlade A, Radeny M, Morton JF and Muchaba T (2018) Rainfall variability and drought characteristics in two agro-climatic zones: an assessment of climate change challenges in Africa. Science of the Total Environment 630: 728-737.

Becker RD (1982) Distribuição dos Sedimentos Cenozóicos na Região Metropolitana de Curitiba e sua Relação com a Estrutura Geológica e Morfológica Regional. PhD thesis, Universidade Federal do Rio Grande do Sul, Porto Alegre, Brazil (in Portuguese).

Behrendt $\mathrm{H}$ and Bachor A (1998) Point and diffuse load of nutrients to the Baltic Sea by river basins of North East Germany (MecklenburgVorpommern). Water Science and Technology 38(10): 147-155.

Bigarella JJ and Salamuni R (1962) Caracteres Texturais dos Sedimentos da Bacia de Curitiba. Departamento de Geologia, Universidade Federal do Paraná, Curitiba, Brazil, Boletim 7 (in Portuguese).

Bollmann HA, Carneiro C and Pegorini ES (2005) Qualidade da água e dinâmica de nutrientes. In Gestão Integrada de Mananciais de Abastecimento Eutrofizados (Andreoli CV and Carneiro C (eds)). Gráf. Capital Ltda, Curitiba, Brazil, pp. 215-270 (in Portuguese).

Danelon OM and Moreira-Nordemann LM (1991) Ocorrência natural e antropogênica de $\mathrm{Cl}^{-}, \mathrm{Na}^{+}, \mathrm{NO}_{3}{ }^{-}, \mathrm{NH}_{4}{ }^{+} \mathrm{e} \mathrm{SO}_{4}{ }^{-2}$ na bacia do rio Quilombo - Cubatão - SP. Revista Brasileira de Geociências 21(1): 96-101 (in Portuguese).

Defew LH, May L and Heal KV (2013) Uncertainties in estimated phosphorus loads as a function of different sampling frequencies and common calculation methods. Marine and Freshwater Research 64(5): 373-386.

Embrapa (1999) Sistema Brasileiro de Classificação de Solos. Centro Nacional de Pesquisa de Solos, Rio de Janeiro, Brazil (in Portuguese).

Erpul G, Gabriels D and Norton LD (2003) The combined effect of wind and rain on interrill erosion processes. Proceedings of College on Soil Physics 2003, Trieste, Italy, pp. 175-182.

Fortin P, Trescases JJ, Melf AJ, Smith JM and Thiry M (1989) Rare earth elements (REE) accumulations in Curitiba basin (Brazil). Proceedings of International Geochemical Exploration Symposium, Rio de Janeiro, Brazil, pp. 66-68.

Franz GAS, Cunha CLN and Gobbi MF (2007) Eutrofização em um reservatório destinado ao abastecimento público: o caso do reservatório do Iraí. Proceedings of XVII Brazilian Symposium of Water Resources, São Paulo, Brazil, pp. 1-20 (in Portuguese).

Hollaway MJ, Beven KJ, Benskin CMWH et al. (2018) A method for uncertainty constraint of catchment discharge and phosphorus load estimates. Hydrological Processes 32(17): 2779-2787, https://doi.org/ 10.1002/hyp. 13217.
Jambers W, Dekov V and Van Grieken R (1999) Single particle characterisation of inorganic and organic North Sea suspension. Marine Chemistry 67(1-2): 17-32.

Kruawal K, Sacher F, Werner A, Müller J and Knepper TP (2005) Chemical water quality in Thailand and its impacts on the drinking water production in Thailand. Science of the Total Environment 340(1-3): 57-70.

Lima MR (2005) Soil Attributes and Floating Macrophytes: a Contribution to Agricultural and Environmental Sustainability in the Irai River Basin. $\mathrm{PhD}$ thesis, Federal University of Paraná State, Curitiba, Brazil.

Mackenthun KM, Ingram WM and Porges R (1964) Limnological Aspects of Recreational Lakes. Public Health Service, Washington, DC, USA.

Ramanathan AL, Subramanian V, Ramesh R, Chidambaram S and James A (1999) Environmental geochemistry of the Pichavaram mangrove ecosystem (tropical) southeast coast of India. Environmental Geology 37(3): 223-233.

Rietzler AC, Fonseca AL and Lopes GP (2001) Heavy metals in tributaries of Pampulha reservoir, Minas Gerais. Brazilian Journal of Biology 61(3): 363-370.

Salamuni E, Salamuni R and Ebert HD (1999) Contribuição à geologia da bacia sedimentar de Curitiba. Boletim Paranaense de Geociências 47: 123-132 (in Portuguese).

Sanepar (2013) Plano Diretor SAIC: Sistema de Abastecimento de Água Integrado de Curitiba e Região Metropolitana. Sanepar, Curitiba, Brazil (in Portuguese).

SGP (State Government of Paraná) (2000) Seleção de Consultoria para Regulamentação e Operacionalização do Sistema Estadual de Gerenciamento de Recursos Hídricos (SEGRH/PR) e do Sistema Integrado de Gestão e Proteção dos Mananciais da Região Metropolitana de Curitiba (SIGPROM/RMC), Curitiba. SGP, Curitiba, Paraná, Brazil (in Portuguese).

Sharpley AN and Halvorson AD (1994) The management of soil phosphorus availability and its impact on surface water quality. In Soil Process and Water Quality: Advances in Soil Science (Lal R and Stewart BA (eds)). Lewis Publishers, Boca Raton, FL, USA, pp. 7-90.

Sharpley AN, Menzel RG, Smith SJ, Rhoades ED and Olness AE (1981) The sorption of soluble phosphorus by soil material during transport in runoff from cropped and grassed watersheds. Journal of Environmental Quality 10(2): 211-215.

Stamm C, Jarvie HP and Scott T (2014) What's more important for managing phosphorus: loads, concentrations or both? Environmental Science \& Technology 48(1): 23-24.

Umweltbundesamt (1997) Daten zur Umwelt-Der Zustand der Umwelt in Deutschland. Umweltbundesamt, Dessau-Roßlau, Germany (in German).

Unesco (UN Educational, Scientific and Cultural Organization) (2015) Water for a Sustainable World: the United Nations World Water Development Report. UN Water, Paris, France.

Unesco (2016) The United Nations World Water Development Report. UN Water, Paris, France.

\section{How can you contribute?}

To discuss this paper, please submit up to 500 words to the editor at journals@ice.org.uk. Your contribution will be forwarded to the author(s) for a reply and, if considered appropriate by the editorial board, it will be published as a discussion in a future issue of the journal. 